\title{
US-JAPAN BURDEN-SHARING DURING THE PRESIDENCY OF DONALD TRUMP
}

\begin{abstract}
This paper analyzes the position of burden sharing between the US and Japan. The study describes the legal, political and military framework of the asymmetric relationship between these two countries and examines the financial conditions of the US military posture in Japan. In this context, several questions were posed: What is the cost sharing arrangement between Washington and Tokyo regarding deployment of the US troops and bases in Japan? What are the legal and financial constraints of Japan in its security relationship with the US? Should we expect any changes in the US - Japan burden sharing and how is that issue related to the US security policy against their European allies? The article uses comparative scientific literature and an analysis of source materials (legal acts, strategies, reports and statements). It argues that the Japanese government should reshape its security obligations aiming to keep the US forces and installations at home.
\end{abstract}

Keywords: burden-sharing, defense expenditures, the US, Japan.

\section{INTRODUCTION}

'Burden sharing' is one of the key elements of the current external US security policy. Washington emphasizes very strongly that allies do not pay enough for the security benefits they receive from the United States. This critic is directed both to NATO European members (Kozlowski, 2019b) and to the Asian and Pacific partners, including Japan. President Donald Trump pointed out that Tokyo needed to increase its share of costs for the US military presence in the country calling the 1951 bilateral security treaty as "one-sided deal that obligates the United States to come to Japan's defense if the country falls under attack" (Shim, 2019).

Current US burden-sharing position vis-à-vis Japan can be explained on several dimensions. First, it represents broad American consensus, that the allies are "free-riders" using the US capabilities to preserve their defence and security with too limited costs. Second, the relationship between Washington and Tokyo cannot be extracted from the very dynamic environment in the Asia and Pacific; growing military and economic potential of China and increasing threat from North Korea bring new challenges to the region, increasing the risks to Japan and its allies. Third, it is directly connected with President's Trump America First policy displaying critical position vis-à-vis international institutions and exposing important or even predominant role of business and economic elements in

\footnotetext{
${ }^{1}$ Grzegorz Kozłowski, PhD in Economics, Ambassador of the Republic of Poland in the Republic of
} Estonia; e-mail: Grzegorz.kozlowski@msz.gov.pl; ORCID: 0000-0002-2025-007X. 
shaping US bi- and multilateral agreements. That has consequences for Tokyo, since Washington abandoned the Trans-Pacific Partnership, preferring to negotiate a bilateral trade agreements under threats of escalating tariffs (Solomon, 2018).

US policy on burden sharing is reflected in the main political documents. National Security Strategy relatively broadly refers to 'burden sharing' stipulating i.e. that "allies and partners magnify our power; we expect them to shoulder a fair share of the burden of responsibility to protect against common threats" (National Security Strategy of the United States, 2017,4). The necessity to remove inequalities in burden sharing have been repeated in the text (i.e. "cooperation means sharing responsibilities and burdens"), however, unlike with an explicit expectations from US to European allies to pay more for defense (National Security Strategy..., p. 48), the document emphasizes that Japan (and other countries from Indo-Pacific region) needs to pursue fair and reciprocal trade. US National Defense Strategy brings similar understanding of the quality and importance of alliances setting expectations towards allies and partners "to contribute an equitable share to our mutually beneficial collective security, including effective investment in modernizing their defense capabilities" (Summary of the 2018 National Defense Strategy of the United States of America, 2018, p. 8).

All above mentioned elements of the US security policy are indicated in the current stance of the dialogue between Washington and Tokyo. The piece would examine a term of burden-sharing, the legal and financial framework of the alliance and the current and prospective understanding of the cost-sharing arrangements between these two countries.

\section{BURDEN SHARING}

There are different definitions and understandings of the term 'burden-sharing'. Historically it is associated with NATO, stemming directly from the art. V of the Washington Treaty, which stipulates that

The Parties agree that an armed attack against one or more of them in Europe or North America shall be considered an attack against them all and consequently they agree that, if such an armed attack occurs, each of them, in exercise of the right of individual or collective self-defence recognised by Article 51 of the Charter of the United Nations, will assist the Party or Parties so attacked by taking forthwith, individually and in concert with the other Parties, such action as it deems necessary, including the use of armed force, to restore and maintain the security of the North Atlantic area (The North Atlantic Treaty, 1949).

This norm can be understood that the building of a defense base capable of responding to the perceived threat is based on the principle that "the burden of defending the West should be shared equitably among the member countries" (United States General Accounting Office, 1990, p. 10). Former US Secretary of Defense Casper Weinberger identified two elements of 'burden-sharing': a. risks and responsibilities of allies need to be (and need to be perceived as) equitably shared and b. contributions of partners, which could include both material (quantifiable) as well as intangible (e.g. political) factors (Weinberger, 1987). The latter corresponds with the evolution of the transatlantic (and non-transatlantic) debate in burden sharing, which can be analyzed not only in terms of financial conditions, but broader as the general contributions to collective security, including humanitarian aid, diplomatic mediation or fight against climate (Foucalt, Mérand, 2012). 
Burden-sharing might be analyzed from different perspectives. First, it has been researched in the literature across the disciplines, including economics, international political economy and international relations (Zyla, 2016) and is mostly associated with economic theory of alliances. In their seminal study, Olson and Zeckhauser interpreted 'security' (output) as a pure public good, where nation's consumption of defence does not affect the amount available for consumption by other nations (non-rivalry) and when the goods are provided, they are available for everyone (non-excludability). That could create an incentive for a nation to 'free-ride' when it knows that other nation will provide sufficient alliance defence for its needs; there will also be a tendency for the bigger members to bear a disproportionate share of the burden (Olson, Zeckhauser, 1966). In the later studies this theory expanded into the joint product (or impure public good) model, which lead to the testable hypothesis that states do not only contribute to the public good exclusively for public, but also for private benefits (Zyla, 2016). Second, current political discussion tends to simplify 'burden-sharing' with the level of defence expenditures. The best example of such debate is NATO. Art. 3 of the North Atlantic Treaty stipulates that "in order more effectively to achieve the objectives of this Treaty, the Parties, separately and jointly, by means of continuous and effective self-help and mutual aid, will maintain and develop their individual and collective capacity to resist armed attack" (North Atlantic Treaty, 1949). The range of these obligations are expressed in the NATO Strategic Concept by full scope of capabilities necessary to deter and defend against any threat to the safety and security of NATO members' territories and populations. Concurrently, art. 19 of the Concept emphasizes (in the last tiret) that member states will sustain "the necessary levels of defence spending, so that our armed forces are sufficiently resourced" (Strategic Concept for the Defence and Security of the Members of NATO, 2010). The "necessary level of defence spending in NATO" is described in art. 14 of the NATO Wales Summit Declaration, which stipulates that Allies will spend at least $2 \%$ of their GDP for defence and will allocate "more than $20 \%$ of their defence budgets on major equipment, including related Research \& Development" (Wales Summit Declaration issued by the Heads of States and Governments participating in the meeting of North Atlantic Council, 2014). Third, burden sharing can also be interpreted as the cost-sharing arrangements between 'sending' and 'receiving' state in terms of common obligations dedicated to the deployment - by the former state - troops on the territory of receiving state. In the alliance terminology it is understood as Host Nations Support (HNS). HNS is defined in the US Department of Defense Dictionary of Military and Associated Terms as "civil and/or military assistance rendered by a nation to foreign forces within its territory during peacetime, crises or emergencies, or war based on agreements mutually concluded between nations" (DOD Dictionary of Military and Associated Terms, 2020). NATO clarifies the aim of HNS as provision of effective support to military activities and to achieving efficiencies and economies of scale "through the best use of a host nation's available resources" (Allied Joint Doctrine for Host Nation Support, 2013). In common usage, HNS can be associated with a broad range of contributions of the host country, most typically identified as either 'cash' or 'in-kind' support, on the one hand, and either 'direct' or indirect' support on the other hand. 
Table 1. Forms of support and illustrative examples of contributions to US from the Host Nation

\begin{tabular}{|c|c|c|}
\hline Type & Direct & Indirect \\
\hline Cash & $\begin{array}{l}\text { Compensation for local national } \\
\text { employees and supplies and services } \\
\text { of US Department of Defense, } \\
\text { including refunds of utilities and } \\
\text { payroll costs. }\end{array}$ & Not applicable \\
\hline In-kind & $\begin{array}{l}\text { - Payments for damage claims; } \\
\text { - Compensation of various kinds to } \\
\text { local communities; } \\
\text { - Direct provisions of labor, land and } \\
\text { infrastructure as well as supplies } \\
\text { and services. }\end{array}$ & $\begin{array}{l}\text { - Forgone rent or lease payments; } \\
\text { - Waivers of customs duties and other } \\
\text { taxes, fees and damage claims. }\end{array}$ \\
\hline
\end{tabular}

Source: (Losumbo, 2013).

US internal regulations precisely defines the scope and the conditions of the Host Nation financial contributions towards US forces stationing abroad (10 US Code par. 2350).

\section{MAIN CHARACTERISTICS OF THE US-JAPAN ALLIANCE}

Japan is one of the closest allies of the United States. Art. 22 par. 2321 k. of the US Code puts Japan - together with Australia, Egypt, Israel, the Republic of Korea and New Zealand - into the category of 'major non-NATO ally'. Department of States outlines bilateral ties between Washington and Tokyo as "the cornerstone of US security interests in Asia and (...) fundamental to regional stability and prosperity" (United States Department of State, 2020). The National Security Strategy of the US determines the relationship with Japan as a: i. long term commitment to support Tokyo to "become successful democracies and among the most prosperous economy in the world"; ii. critical ally to respond to threat (like e.g. stemming from the North Korean policy) in the IndoPacific region ("we welcome and support strong leadership role of our critical ally, Japan") and iii. partner in cooperation on missile defense (US "will cooperate on missile defense with Japan....to move toward an area defense capability”) (National Security Strategy..., 2017).

Treaty of Mutual Cooperation and Security between the United States of America and Japan is the legal foundation of the bilateral relations between Washington and Tokyo. Article V of this Treaty stipulates that

Each Party recognizes that an armed attack against either Party in the territories under the administration of Japan would be dangerous to its own peace and safety and declares that it would act to meet the common danger in accordance with its constitutional provisions and processes (Treaty of Mutual Cooperation and Security between the United States of America and Japan, 1960).

Simultaneously, article III states that "the Parties, individually and in cooperation with each other, by means of continuous and effective self-help and mutual aid will maintain and develop, subject to their constitutional provisions, their capacities to resist armed attack". These norms in clearly asymmetric approach define the right and obligations of both parties. 
Unlike in the NATO Charter, commitments to defence concern only one party covering the territory of Japan, and not the territory of the Unite States. As Robert F. Reed emphasizes „Japan is committed to act only when under attack itself or when US forces within Japan are attacked. There is no obligation to come to the aid of the United States if attack occurs anywhere outside Japanese territory" (Reed, 1983, p. 9). Simultaneously, they refer to constitutional provisions of both countries. The key considerations can be taken from the text of the Japanese charter, which strictly limits the use of force by Tokyo. Article 9 of the Constitution of Japan specifies that

the Japanese people forever renounce war as a sovereign right of the nation and the threat or use of force as means of settling international disputes. (...) land, sea, and air forces as well as war potential, will never be maintained. The right of belligerency of the state will not be recognized (The Constitution of Japan, 1946).

This norm has been a matter of evaluation and interpretation by doctrine, which came to the conclusion that Tokyo can - under certain circumstances (self-defence and participation in the non-combat operations) and in a limited scope - use forces. Ministry of Japan recognizes the meaning of its own defence-oriented policy as

the force is used only in the event of an attack (...) the extent of the use of defensive force is kept to the minimum necessary for self-defense and that the defense capabilities to be possessed and maintained by Japan are limited to the minimum necessary for self-defense (Ministry of Defense of Japan, 2018).

Legal constraints are not the only limitation on the Japanese side. Tokyo decided in 1976 that defence budget would be limited to not more than $1 \%$ of GDP. Since its pronouncement, this ceiling has become not only a psychological barrier to comprehensive defense planning, but also an element of Japanese 'security culture', which puts defence expenditures in certain political and historical framework. It limits (or even blocks) the readiness of Tokyo to increase defence spending (especially in the context of relatively low growth of national income and big public debt), while leading to broadening of perception of the scope and the role of military expenditures. For Japan - like for Germany (Kozlowski, 2019a) - security cannot be narrowed down to military spending; development aid and humanitarian assistance also count as contributions to global security.

Japan places $9^{\text {th }}$ position in the world in terms of defence spending. In 2019 it allocated in this regard 47.6 bln USD and has $2.5 \%$ of the world of defense expenditures. Simultaneously, the level of GDP spending was the lowest among ten biggest spenders, which was lower by 1 percentage point vis-à-vis China and 1.8 point against South Korea.

While US-Japan bilateral security relationship is clearly asymmetric with Tokyo relying on the support from Washington, the economic collaboration can be characterized by Japanese trade competitiveness (within the years 2010-2019 US deficit against Japan ranged between 63 and 76 billion USD per year) (United States Census Bureau, 2020). That has direct and obvious consequences for the Washington's policy vis-à-vis Tokyo; to win trade concessions (e.g. purchase of American defense equipment) US is using the argument of its own defense commitments. As Awonahara states "trade and defense issues have also been combined when the United States has limited imports of Japanese products for national security reasons. As Japan continues to make major strides in dual-use technology, it will 
become increasingly difficult to separate trade and defense issues" (Awonahara, 1990, p. 5).

Table 2. The World's biggest spenders on defense (2019)

\begin{tabular}{|l|c|c|c|}
\hline Country & Amount in bln USD & Share of GDP in \% & World share in \% \\
\hline 1. USA & $\mathbf{7 3 2}$ & $\mathbf{3 . 4}$ & $\mathbf{3 8}$ \\
\hline 2. China & 261 & 1.9 & 14 \\
\hline 3. India & 71.1 & 2.4 & 3.7 \\
\hline 4. Russia & 65.1 & 3.9 & 3.4 \\
\hline 5. Saudi Arabia & 61.9 & 8.0 & 3.2 \\
\hline 6. France & 50.1 & 1.9 & 2.6 \\
\hline 7. Germany & 49.3 & 1.3 & 2.6 \\
\hline 8. United Kingdom & 48.7 & 1.7 & 2.5 \\
\hline 9. Japan & $\mathbf{4 7 . 6}$ & $\mathbf{0 . 9}$ & $\mathbf{2 . 5}$ \\
\hline 10. South Korea & 43.9 & 2.7 & 2.3 \\
\hline
\end{tabular}

Source: SIPRI (Stockholm International Peace Research Institute), 2019.

\section{BURDEN SHARING IN THE HISTORY OF THE POSTWAR US-JAPAN RELATIONS}

The 1950s and 1960s security arrangement between US and Japan indicated willingness of Washington to assume the financial burden of defending Japan and maintaining regional security in the Far East. The United States agreed to provide troops and pay for all related expenses and Japan consented to bestow military bases and facilities. Even though this formal arrangement has in general terms remained unchanged, the character of the alliance between Washington and Tokyo has been dynamically evolving during the last 75 years, which had also direct consequences for a burden sharing settings (United States General Accounting Office, 1989).

In a broad sense, US burden sharing demands on the government in Tokyo started already in the late 1940s, but the real pressure started in the mid-1960s, when Japan had begun to accumulate trade surpluses with the United States. The idea of burden-sharing was implicit in the President's Richard Nixon Guam Doctrine of 1969, in which he called on friendly countries (including Japan) to accept financial burden of their own conventional defence (Awonahara, 1990). These expectations grew especially in 1970s when the stationing costs for US forces in Japan sharply increased. US dollar weakened in the relation to the yen ${ }^{2}$, while the construction costs and labor wages were augmenting; it made longterm, unilateral sustainment of US bases less economically feasible whereas Japanese economy was at the same time flourishing. That must have led to negotiating in 1978 host nation support agreement, which reduced the financial burden on US forces (Bosack, 2019).

Despite these arrangements, burden-sharing demands became acute during the administrations of Presidents Jimmy Carter (1977-1981) and Ronald Reagan (1981-1989). The White House expected specific, often quantitative, commitments from Tokyo on its

${ }^{2}$ Up until 1971, the yen was pegged with a fixed exchange rate of 360 yen to the dollar; by 1978, the rate was already plummeting below 200 yen. 
defense buildup and Congress was sharing and even amplifying that approach. In 1981 Senator Jesse Helms (R-NC) proposed a renegotiation of the US-Japan security treaty to make it reciprocal arrangement, while Congressman Stephen Neal (D-NC) demanded from Japan to share the burden by allocating at least $2 \%$ of its Gross National Product (GNP) to defense (see later part of this article). In 1982, in a letter to the Japanese Prime Minister Zenkō Suzuki, 66 members of Congress urged Tokyo to spend a greater percentage of its GNP for defense due to counter the increased Soviet threat. In the following years (1983, 1985 and 1987) members of the House of Representatives suggested that Japan either increases its defense spending or face US penalties (among proposals: tariff surcharges or a security tax on Japanese imports and relocating some of the US troops in Japan to other areas of the Western Pacific). The burden sharing debate between US and Japan in 1980s was particularly intense since the US suffered from a severe economic recession caused by both the increase of military expenditure and a growing national budget deficit (Satake, 2012). A 1988 House Armed Services Committee interim report on burden sharing reflected the frustration of American authorities. The report said that "many Americans feel that we are competing 100 percent militarily with the Soviets and 100 percent economically with our defense allies" and stated i.e. that: a. Japan's defense contributions and capabilities are inadequate given its tremendous economic strength; b. Japanese HNS for US service personnel is overstated; c. Japanese Government needs to accelerate its ability to perform the self-defense missions without direct US assistance and d. Japan should increase its official development assistance substantially and should target aid towards countries which have strategic importance for Washington and Tokyo (Committee on Armed Services, House of Representatives, 1988).

The post-Cold War era faces new types of threats such as terrorism, nuclear proliferations, ethnic conflicts and others. The US capacity to address these threats has been in relative decline, which is one of the reason the Washington began to further demand more burden-sharing from Japan in 1990s (Kohno, 1999).

Over the next decades, the burden sharing discussions and the host nations arrangement between US and Japan have been evolving. They resulted in more defence efforts from Japan, including dispatching in 2003 the Maritime Self-Defence Force to the Indian Ocean to provide logistical support for US military operations and sending in 2003 forces to aid in Iraq's postwar reconstruction efforts (Maizland, Xu, 2019). They also shaped financial arrangements, which was agreed in 1987 as the Special Measures Agreement and was amended since that time every five years. Although the US expectations vis-à-vis Japan to balance some of the American costs continued, only the presidency of Donald Trump brought unprecedented pressure towards Japan and other allies in that regard.

\section{BURDEN-SHARING ARRANGEMENTS}

Art. VI of the Treaty of Mutual Cooperation and Security states that „for the purposes of contributing to the security of Japan and maintenance of international peace and security in the Far East, The United States of America is granted the by its land, air and naval forces of facilities and areas in Japan" (Treaty of Mutual Cooperation and Security, 1960). This norm was specified in the Status of Forces Agreement (SOFA; rights and obligations of US stationing troops in Japan), which defines that Japan was to furnish, without cost to the United States, facilities and areas for the use of US forces in Japan. Simultaneously, US agreed to bear without cost to Japan all expenses incident to the maintenance of these forces 
(Reed, 1983). The other important documents constituting rights and obligations of both sides on burden sharing are Special Measures Agreement (SMA) and Facilities Improvement Program (FIP) - see below.

Up until 2004, Department of Defense provided aggregate national-level information on direct and indirect cost sharing and other forms of contributions toward the common defense and mutual security of the US and its allies. According to the last report Japan's yearly contribution under the Host Nation Support 4.4 million USD, which constituted $74.5 \%$ of US stationing costs (US Department of Defense, 2004). The data for recent years are unfortunately less available, since there are no centralized sources of information on contributions or US payments, other than those pertaining to cash support and multilateral cost sharing (Losumbo, 2013). According to different information, Tokyo's contribution towards US military posture in Japan ranges from $40 \%$ (various media reports) to $86 \%$ (Japanese Government) (Chanlett-Avery, 2019).

Table 3. US Forces in Japan

\begin{tabular}{|c|c|}
\hline US Forces & Number of troops \\
\hline Navy & 20.250 sailors \\
\hline Air Force & 12.500 airmen \\
\hline Army & 2.700 soldiers \\
\hline Marine Corps & 18.800 marines \\
\hline
\end{tabular}

Source: (Chanlett-Avery et al., 2019).

Burden-sharing arrangements between Japan and USA can be interpreted on three dimensions. First, Tokyo provides to the US Army Host Nation Support. HNS is composed of two funding sources: SMA and FIP. SMA is a bilateral agreement, covering usually five years, which obligates Japan to pay a certain amount for utility and labor costs of US bases and for relocating training exercises away from populated areas. Under the current SMA (2016-2021), Tokyo contributes circa 1.7 billion USD per year and at least 187 million USD for the FIP (this funding is not strictly defined, other than the agreed minimum). FIP (initiated in 1978 to provide housing for the US military personnel) is not included in SMA and has a voluntary character (Inquiry into US Costs and Allied Contributions to Support the US Military Presence Overseas, 2013). According to Chanlett-Avery both sums set the Japanese contribution under HNS (in-kind and cash) in the range of 1.7-2.1 billion USD per year to offset the direct cost of stationing of US forces in Japan (Chanlett-Avery, 2019). Second, Japan spends approximately 1.65 billion USD annually on measures to subsidize or compensate base-hosting communities. Upon the norms outlined in the US-Japan Mutual Security Treaty, Tokyo also pays the cost of relocating US bases within Japan and rent to any landowners on which US military facilities are located in Japan. That includes i.e. covering of majority of costs regarding three of the largest international military base construction projects since World War II (replacement facility in Okinawa - 12.1 billion USD; air station Iwakuni - over 4.5 billion USD and facilities in Guam - 3.1 billion USD) (Chanlett-Avery, 2019). According to the Ministry of Defense of Japan, these costs in the 2016 budget reached a level of approximately 1.6 billion of USD (Ministry of Defense of Japan, 2016). Third, Japanese financial contributions to the United States have to be seen 
in the wider context of close political and military collaboration between the two countries. Tokyo has been a major purchaser of US-produced defense equipment (more than $90 \%$ of equipment comes from US) being the major recipient of the Department of Defense Foreign Military Sales program (on the level of 3 billion USD yearly). Japan provides an economic aid to strategically important countries (Islam, 1993); only in 2018 Japanese contribution under Official Development Assistance grant equals to 14.2 billion USD; top three recipients of Japanese aid were India, Bangladesh and Viet Nam (Organisation for Economic Cooperation and Development, 2019). Simultaneously, Tokyo supports Washington in peacekeeping efforts. Despite restrictive legislation (limiting deployment to settings in which cease-fire is in place and use of force is reduced to self-defence), Japan has already been able to deploy since 1992 more than 10 thousand personnel to peacekeeping missions (Hutchinson, Day, 2018). Japan plays also an important role for US in terms of cooperation in defense technology and security cooperation (e.g. through US Ballistic Missile Defense capabilities).

Based on the available data from Ministry of Defense of Japan and RAND we can assume that the Tokyo's costs for the stationing of US troops on its territory can be shown as presented in table 4 .

Table 4. US Forces Japan-related Costs (Budget for FY2016)

\begin{tabular}{|c|c|}
\hline Types of costs & Million USD $^{3}$ \\
\hline $\begin{array}{l}\text { Costs clearly covered under Ministry of Defense (MOD) budget documents, } \\
\text { labeled as "Cost-Sharing for the stationing of US Forces in Japan". }\end{array}$ & 1.776 \\
\hline $\begin{array}{l}\text { Costs likely covered under MOD budget documents as base promotion, } \\
\text { including measures to improve surrounding living environments and facilities } \\
\text { rent. }\end{array}$ & 1.704 \\
\hline $\begin{array}{l}\text { Costs additional to those covered under MOD budget documents (i.e. } \\
\text { expenditures borne by non-MOD Ministries). }\end{array}$ & 1.650 \\
\hline Total & 5.130 \\
\hline
\end{tabular}

Source: (Ministry of Defense of Japan, 2016 and Losumbo et al., 2013).

Annual Japanese support (direct and indirect) for the US stationing forces could be estimated on the level of just over 5 billion USD. Taking into account that the US pays for their troops in Japan approximately 2 billion USD (Hoff, 2016), Tokyo's share in overall costs could reach just over $70 \%$.

\section{BURDEN SHARING IN THE CURRENT AND FUTURE PERSPECTIVE OF US-JAPAN RELATIONSHIP}

President Donald Trump has repeatedly questioned the economics of US global security alliances saying that the countries Washington protects must "pay up". Trump emphasized that the allies are "not paying enough their share" and they "must contribute toward their financial, political, and human costs". He warned that the countries US are defending "must

\footnotetext{
31 USD-108.69 Yen (average closing price from 2016). Dollar Yen Exchange Rate - Historical Data Chart. [Access: 8 September 2020]. Access on the internet: https://www.macrotrends.net/ 2550/dollar-yen-exchange-rate-historical-chart.
} 
pay for the cost of this defense, and if not, the US must be prepared to let these countries defend themselves" (Transcript: Donald Trump's Foreign Policy Speech, 2016). Trump contended that Japan should pay more host-nation support of face a drawback of US defense commitments. These expectations were strengthened in the last several years; the most exorbitant demand reached the so called "Cost Plus 50" formula, which is defined that Japan (or any other country hosting US troops) pay the full price of American soldiers deployed on their soil plus $50 \%$ or more for the privilege of hosting them (Wadhams, Jacobs, 2018).

President's Trump rhetoric created real and effective pressure on the NATO allies. Jens Stoltenberg, NATO Secretary General, announced in November 2019 (ahead of the Alliance summit in London) that defense spending across European Allies and Canada increased in real terms by $4.6 \%$ and revealed that the Allies would invest in defense by the end of 2020130 billion USD more than in 2016 (NATO HQ, 2019).

Table 5. NATO defence expenditures dynamic of growth (2016-2019)

\begin{tabular}{|l|c|c|c|c|c|c|}
\hline \multirow{2}{*}{ Regions } & \multicolumn{2}{|c|}{$\mathbf{2 0 1 6}$} & \multicolumn{2}{c|}{$\mathbf{2 0 1 9}$} & \multicolumn{2}{c|}{ Change (2019/2016) } \\
\cline { 2 - 7 } & $\begin{array}{c}\text { billion }^{4} \\
\text { USD }\end{array}$ & $\%$ GDP & $\begin{array}{c}\text { billion } \\
\text { USD }\end{array}$ & $\%$ GDP & $\begin{array}{c}\text { billion } \\
\text { USD }\end{array}$ & \% GDP \\
\hline $\begin{array}{l}\text { NATO Europe } \\
\text { and Canada }\end{array}$ & 255,3 & 1.44 & 309,5 & 1.57 & 54,2 & 0.13 \\
\hline NATO Total & 911,4 & 2.49 & $1.039,6$ & 2.52 & 128,2 & 0.03 \\
\hline
\end{tabular}

Source: (NATO HQ, 2019).

Data in table 5 proved the real increase of defence expenditures among NATO allies (54 billion USD in the case of European countries and Canada). However, some of them, have been still keeping their outlays under NATO guidelines, which is at least $2 \%$ of GDP. The most tensed US critic was addressed toward Germany (Herszenhorn, 2019), which finally has consequences for the American presence in this country. As US Department of Defense announces in July 2020, approximately 11,900 military personnel will be repositioned from Germany with nearly 5,600 repositioned within other NATO countries and 6,400 returning to the United States to address readiness and prepare for rotational deployments (US Department of Defense, 2020). According to President Trump the reason for this decision was mostly financial as Germany are not paying their bills (Borger, 2020). The same pressure is addressed towards non-NATO allies. In currently negotiating agreement between Washington and Seoul, the White House expects that South Korea radically (even up to five fold from the current level 920 million USD) increase its support for the US stationing forces in its country, suggesting that without such a move, withdrawal of troops could be decided (Klinger, 2020).

Under current and prospective circumstances, there will be a continued Washington's pressure on Tokyo to increase Japanese contribution in bilateral burden sharing. Potential change on the position of the US President in the upcoming in November 2020 presidential election (Democrats' candidate Joe Biden succeeding president Trump) would not alter much, since there is a bipartisan consensus in the US Congress to expect more from

\footnotetext{
${ }^{4}$ Current prices and exchange rates.
} 
the allies in terms of financial engagement and no one can argue that the White House policy brought changes in the policy of European allies in terms of defense spending (see table 5).

In that context, Tokyo - trying to keep close political, military and economic relations, especially in the era of growing interests from China and remaining nuclear threat from North Korea - will have to adjust its policy vis-à-vis Washington, Japan remains a nonnuclear weapons state, being a signatory to the Treaty on the Proliferation of Nuclear Weapons. While it has to be underlined that Japan acquired from the US highly potent Ballistic Missile Defense capabilities and continued to advance bilateral cooperation with US in that regard, but Tokyo has to rely - especially in the context of growing concerns coming from North Korean nuclear weapons development and China's modernization of its nuclear arsenal - on the US policy of extended deterrence (commonly known as the "nuclear umbrella"). The defense of Japan against atomic threats from Pyongyang is explicitly reflected in the US Nuclear Posture (US Department of Defense, 2018). US nuclear guarantee is de facto the most important factor (apart from bilateral Treaty rights and obligations see above) determining asymmetric position between US and Japan and shaping the status of Tokyo to large extent as a free rider.

Having no real alternatives than to increase its financial burden vis-à-vis US, Japan will have limited sphere of maneuvering. Unlike some of the European allies, Japan does not have a possibility to increase (or even plan to increase) its defense expenditures. Current and ongoing political requirements to keep the ceiling of allocation not more of 1\% of GDP for defense will maintain the Japanese Government against US expectations to spend more for defense without "room for maneuver". Tokyo has also limited flexibility in some of the indirect contribution, which would serve US interest. It cannot radically enhance of purchasing of US defense equipment (Japan already buys more than $90 \%$ of military goods from US); simultaneously current US administrations is not very enthusiastically interested in development assistance spending.

Where are the potential concessions of Japan? First, Tokyo has to be ready to reshape SMA in favor of Washington. Japan can - as Bosack suggested - identify new existing areas to include into the SMA and should be open to negotiate increases in existing cost-sharing areas (Bosack, 2019). That would directly benefit Washington by decreasing its costs of US stationing in Japan. Second, Tokyo needs to consider further progressing its defense policy with more emphasis on increasing its defense capabilities and the role in the peacekeeping operations. Third, the key to burden sharing might be economic (trade) area, where Japan can consider further compromises toward US. The old Japanese policy of separation defence and trade cannot be further maintained in the relationship with US.

\section{CONCLUSIONS}

Burden sharing remains one of the priorities of the current US Government. Washington expects that Japan, like a lot of European allies of US, will be prone to increase its security and financial contributions regarding the stationing of the American troops in Japan and in broader terms - aiming to support US interest in the Indo-Pacific region and globally.

Tokyo will not be able to avoid increasing its economic and military engagement in the alliance with the US. Asymmetric character of relationship with a clear significance of US nuclear capabilities would make Japan induced to grant Washington more concessions. 
However, having legal and financial constraints and being not ready to increase its defense spending over $1 \%$ of GDP, Japan will seek to grow its contribution under present cost sharing arrangements (like SMA), while pursuing other, indirect forms of support of the United States in defense related areas.

\section{REFERENCES}

Allied Joint Doctrine for Host Nation Support (2013) [Access:25.08.2020]. Access on the internet: https://assets.publishing.service.gov.uk/government/uploads/system/uploads/ attachment_data/file/628308/ajp-4.5_edb_v1_e.pdf.

Awonahara, S. (1990). The Burden-Sharing Issues in US-Japan Security Relations. A Perspective from Japan. Honolulu: East-West Center [Access:1.09.2020]. Access on the internet: https://scholarspace.manoa.hawaii.edu/bitstream/10125/23828/

BurdenSharingIssuesInUSJapanSecurityRelations1990\%5Bpdfa\%5D.PDF.

Borger, J. (2020). US to pull 12,000 troops out of Germany as Trump blasts 'delinquent' Berlin. "The Guardian". [Access:9.09.2020]. Access on the internet: https://www.theguardian. com/us-news/2020/jul/29/us-germany-troop-withdrawal-donald-trump.

Bosack, M.M. (2019). The Looming Cost-Sharing Storm. Mitigating the Impacts of Special Measures Agreement Negotiations on the US-Japan Alliance. Sasakawa US Forum, Issue No 18 [Access: 1.09.2020]. Access on the internet: https://spfusa.org/wp-content/uploads/2019/05/ The-Looming-Cost-Sharing-Storm_Bosack.-formatted.pdf.

US Census Bureau (2020). Trade in Goods with Japan [Access: 4.09.2020]. Access on the internet: https://www.census.gov/foreign-trade/balance/c5880.html.

Chanlett-Avery, E. et al (2019). The US-Japan Alliance, Washington: Congressional Research Service [Access: 7.09.2020]. Access on the internet: https://fas.org/sgp/crs/row/RL33740.pdf.

U.S. Code no date [Access: 1.09.2020]. Access on the internet: https://www.law.cornell.edu/ uscode/text/10/2350j.

Committee on Armed Services. US House of Representatives (1988). Interim Report of the Defense Burdensharing Panel. Washington: US Government Printing Office.

Committee on Armed Services, US Senate (2013). Inquiry into US Costs and Allied Contributions to Support the US Military Presence Overseas [Access: 8.09.2020]. Access on the internet: https://www.armed-services.senate.gov/imo/media/doc/REPORT-FOR-POSTING-416-2013-WITH-5-14-2013-CORRECTION.pdf.

The Constitution of Japan (1946) [Access: 6.09.2020]. Access on the internet: https://japan.kantei.go.jp/constitution_and_government_of_japan/constitution_e.html.

US Department of Defense (2004). 2004 Statistical Compendium on Allied Contributions to the Common Defense. [Access: 7.09.2020]. Access on the internet: https://archive.defense.gov/ pubs/allied_contrib2004/allied2004.pdf.

US Department of Defense (2018). Summary of the 2018 National Defense Strategy of the United States of America. Sharpening the American Military Competitive Edge, [Access: 27.08.2020]. Access on the internet: https://dod.defense.gov/Portals/1/Documents/pubs/2018National-Defense-Strategy-Summary.pdf.

US Department of Defense (2018). "Nuclear Posture Review" [Access: 10.09.2020]. Access on the internet: https://dod.defense.gov/News/SpecialReports/2018NuclearPostureReview.aspx.

US Department of Defense (2020). US European Command Force Posture Review [Access: 9.09.2020]. Access on the internet: https://www.defense.gov/Newsroom/Releases/Release/ 
Article/2292244/department-of-defense-statement-us-european-command-force-posturereview/source/GovDelivery/.

DOD Dictionary of Military and Associated Terms (2020) [Access: 25.08.2020]. Access on the internet: https://www.jcs.mil/Portals/36/Documents/Doctrine/pubs/dictionary.pdf.

US Department of State (2020) US Relations With Japan. Bilateral Fact Sheet [Access: 4.09.2020]. Access on the internet: https://www.state.gov/u-s-relations-with-japan/.

Foucault, M., Mérand, F. (2012). The challenge of burden-sharing. "International Journal", Vol. 67, No 2 .

US General Accounting Office (1989). US-Japan Burden Sharing. Japan has Increased Its Contributions, but Could Do More. [Access:1.09.2020]. Access on the internet: https://www.gao.gov/assets/150/148034.pdf.

US General Accounting Office (1990). US-NATO Burden Sharing. Allies' Contributions to Common Defense. [Access: 27.08.2020]. Access on the internet: https://www.gao.gov/ assets/150/149781.pdf.

Herszenhorn, D. (2019). Trump threatens to punish Germany over military spending. Politico [Access: 9.09.2020]. Access on the internet: https://www.politico.eu/article/donald-trumpthreatens-germany-military-spending/.

Hoff, R. (2016). Burden-Sharing with Allies: Examining the Budgetary Realities. American Action Forum [Access: 9.09.2020]. Access on the internet: https://www.americanactionforum. org/research/burden-sharing-allies-examining-budgetary-realities/.

Hutchinson, E., Day, A. (2018). Is the Cruz Report the end of peacekeeping for Japan?. "Japan Times" [Access: 8.09.2020]. Access on the internet: https://www.japantimes.co.jp/opinion/ 2018/06/12/commentary/japan-commentary/cruz-report-end-peacekeeping-japan/.

Islam, S. (1993). Foreign Aid and Burdensharing: Is Japan Free Riding to a Coprosperity Sphere in Pacific Asia [In:] Frankel, J., Kahler, M., Regionalism and Rivalry: Japan and the United States in Pacific Asia, Chicago: University of Chicago Press.

Klinger, B. (2020). US-South Korea Burden-Sharing Talk Remain Stuck. Here's How to Fix It. Heritage Foundation [Access: 9.09.2020]. Access on the internet: https://www.heritage.org/asia/ commentary/us-south-korea-burden-sharing-talk-remain-stuck-heres-how-fix-it.

Kohno, M. (1999). In Search of Proactive Diplomacy: Increasing Japan's International Role in the 1990s. Brookings Institute [Access: 3.09.2020]. Access on the internet: https://www. brookings.edu/research/in-search-of-proactive-diplomacy-increasing-japans-international-rolein-the-1990s/.

Kozlowski, G. (2019a). NATO Defence Expenditures and the Baltic Member-States [In:] Voyger, M., ed., NATO at 70 and the Baltic States: Strengthening the Euro-Atlantic Alliance in an Age of Non-Linear Threats, Tartu: The Baltic Defence College.

Kozlowski, G. (2019b). The Position of Burden Sharing the Current US Security Policy vis-àvis European Allies. "Baltic Journal of European Studies”, Vol. 9, No 4 (29).

Losumbo, M. et al. (2013). Overseas Basing of U.S. Military Forces: An Assessment of Relative Costs and Strategic Benefits. Santa Monica: RAND Corporation.

Maizland, L., Xu, B. (2019). The US-Japan Security Alliance. Council of Foreign Relations [Access: 3.09.2020]. Access on the internet: https://www.cfr.org/backgrounder/us-japansecurity-alliance.

Ministry of Defense of Japan (2016). Defense of Japan [Access: 8.09.2020]. Access on the internet: https://www.mod.go.jp/e/publ/w_paper/pdf/2016/DOJ2016_2-4-4_web.pdf. 
Ministry of Defense of Japan (2018). Defense of Japan [Access: 6.09.2020]. Access on the internet: https://www.mod.go.jp/e/publ/w_paper/pdf/2018/DOJ2018_Full_1130.pdf.

NATO HQ (1949). The North Atlantic Treaty [Access: 27.08.2020]. Access on the internet: https://www.nato.int/nato_static_fl2014/assets/pdf/stock_publications/20120822_nato_treaty_ en_light_2009.

NATO HQ (2010). Strategic Concept for the Defence and Security of the Members of the North Atlantic Treaty Organization [Access: 31.08.2020]. Access on the internet: https://www. nato.int/strategic-concept/pdf/Strat_Concept_web_en.pdf.

NATO HQ (2014). Wales Summit Declaration issued by the Heads of State and Government participating in the meeting of the North Atlantic Council in Wales [Access: 31.08.2020]. Access on the internet: https://www.nato.int/cps/en/natohq/official_texts_112964.htm.

NATO HQ (2019). NATO Secretary General announces increased defence spending by Allies [Access: 9.09.2020]. Access on the internet: https://www.nato.int/cps/en/natohq/news_171458. htm? selectedLocale $=$ en.

"The New York Times" (2016). Transcript: Donald Trump's Foreign Policy Speech [Access: 9.09.2020]. Access on the internet: https://www.nytimes.com/2016/04/28/us/politics/transcripttrump-foreign-policy.html.

OECD (2019). Development Co-operation Report. 2019: A Fairer, Greener, Safer Tomorrow, Paris: OECD Publishing.

Olson, M., Zeckhauser, R. (1966). An Economic Theory of Alliances. "Review of Economics and Statistics", No. 48.

Reed, R.F. (1983). The US-Japan Alliance: Sharing the Burden of Defense. Washington: National Defense University Press.

Satake, T. (2012). Japan, Australia and International Security Burden-Sharing with the United States [In:] Tow, W.T., Kersten, R., eds., Bilateral Perspectives on Regional Security. Australia, Japan and the Asia-Pacific Region. London: Palgrave Macmillan.

Shim, E. (2019). Report: Bolton discussed fivefold increase in military burden sharing in Japan. United Press International [Access: 26.08.2020]. Access on the internet: https://www. upi.com/Top_News/World-News/2019/07/31/Report-Bolton-discussed-fivefold-increase-inmilitary-burden-sharing-in-Japan/7201564580052/.

SIPRI (2020). Trends in World Military Expenditure [Access: 6.09.2020]. Access on the internet: https://www.sipri.org/sites/default/files/2020-04/fs_2020_04_milex_0_0.pdf.

Solomon, R. (2018). Japan Must Do More to Support the US-Japan Alliance. The Diplomat [Access: 26.08.2020]. Access on the internet: https://thediplomat.com/2018/09/japan-must-domore-to-support-the-us-japan-alliance/.

Treaty of Mutual Cooperation and Security between the United States of America and Japan (1960) [Access: 4.09.2020]. Access on the internet: http://afe.easia.columbia.edu/ps/japan/ mutual_cooperation_treaty.pdf.

Wadhams, N., Jacobs, J. (2019). Trump Seeks Huge Premium From Allies Hosting US Troops. Bloomberg [Access: 3.09.2020]. Access on the internet: https://www.bloomberg.com/ news/articles/2019-03-08/trump-said-to-seek-huge-premium-from-allies-hosting-u-s-troops.

Weinberger, C. (1987). Report on Allied Contributions to the Common Defense. A Report to the United States Congress [Access:27.08.2020]. Access on the internet: https://apps.dtic.mil/ dtic/tr/fulltext/u2/a192414.pdf. 
The White House (2017). National Security Strategy of the United States of America [Access: 27.08.2020]. Access on the internet: https://www.whitehouse.gov/wp-content/uploads/2017/12/ NSS-Final-12-18-2017-0905.pdf.

Zyla, B. (2016). NATO Burden Sharing: A New Research Agenda. “Journal of International Organizations Studies”, Vol. 7, Issue 2.

DOI: $10.7862 /$ rz.2020.hss.42

The text was submitted to the editorial office: October 2020.

The text was accepted for publication: December 2020. 
